\title{
RELATIONSHIP BETWEEN CORPORATE SOCIAL RESPONSIBILITY AND BUSINESS SUCCESS: CASE OF THE GLOBAL TOBACCO INDUSTRY
}

\author{
Marcela Mišura* \\ Ljerka Cerovic ${ }^{* *}$ \\ Vesna Buterin ${ }^{* * *}$
}

Received: 6. 9. 2017

Preliminary communication

Accepted: 7. 4. 2018

UDC 005.915:005.35>663.97

DOI https://doi.org/10.30924/mjcmi/2018.23.1.157

\begin{abstract}
This study evaluates the relationship between corporate social responsibility (CSR) and the financial performance of companies operating within the global tobacco industry. According to the Forbes Global 2000 list, the research covers almost the entire industry, more accurately nine companies whose value is about $99 \%$ of the total market capitalization of the industry. Analysis of this research problem covered a five-year period, from 2011 to 2015. To evaluate CSR of the companies involved in research, the CSRHub rating list was used. An aforementioned list gives ratings for the four criteria of CSR: community, employees, environment, and governance. To assess
\end{abstract}

\section{INTRODUCTION}

It is expected that modern companies contribute to social well-being with their business activities. Particular emphasis is placed on multinational corporations which, as "global citizens", have a strong impact on society. It is clear that the growth model of the financial performance of the companies and to obtain representative results, two indicators were used: ROA, as a measure based on the accounting records of the company and Tobin's $Q$ ratio, as a measure of the market success of the company. The research results indicate that there is no statistically significant correlation between the CSR and the financial performance at the tobacco industry level, but statistically significant correlation can be confirmed only selectively at the level of individual companies and individual indicators.

Keywords: corporate social responsibility, the tobacco industry, financial performance

a company which in its strategy does not include the socially responsible activities is not sustainable long-term.

In current studies, the relationship between CSR and the company's financial success is strongly considered. The results of such studies vary from the positive

\footnotetext{
${ }^{*}$ Marcela Mišura, PhD Candidate at Faculty of Economics, University of Rijeka, Croatia, Phone: +38595 5708 497, e-mail: mmisura55@gmail.com

${ }^{* *}$ Ljerka Cerović, PhD, professor, Faculty of Economics, University of Rijeka, Croatia, Ivana Filipovića 4, Rijeka, Phone: +385 51355 147, e-mail: ljerka.cerovic@efri.hr

${ }^{* * *}$ Vesna Buterin, PhD, assistant professor, Faculty of Economics, University of Rijeka, Croatia, Ivana Filipovića 4, Rijeka, Phone:+385 51355 122, e-mail: vesna.buterin@efri.hr
} 
effects, through neutral to negative effects. According to Margolis and Walsh (2003), who summarized over 120 studies between 1971 and 2001, examining the empirical relationship between CSR and financial performance, the results were inconsistent. These differences in results can be partly explained by the various criteria, variables, and methodology that the scholars used as the input parameters of analyses. Nevertheless, majority of studies on this subject show a positive relationship between CSR and business success of companies. On that trail, Choi et al. (2010, 291) "find a positive and significant relationship between corporate financial performance and the stakeholderweighted CSR index, but not the equalweighted CSR index". Jo and Harjoto (2011) provide additional insight on CSR' strong impact on US firms' market value, measured by Tobin's Q ratio.

Another aspect of this issue is the fact that the relationship between CSR and financial performance of the company is differently assessed in the existing literature, which makes the topic particularly interesting for further research. Although there are numerous papers dealing with this topic, the CSR level is usually defined only binary, with grade 0 (the company is not socially responsible) or 1 (the company is socially responsible) and the financial indicators of a company that is (not) socially responsible are calculated consequently.

Even though forty years ago Sturdivant and Ginter (1977) emphasized the need to take the entire industry into account when studying CSR, there is an evident lack of comprehensive studies on this topic (the relationship between CSR and company's financial performance) at the industry level, especially in controversial industries, such as the tobacco industry. This industry is faced with increasingly rigorous legislation and invests great efforts in shaping the society's perception of the industry and its products being placed on the market.

The purpose of this paper is to draw attention to the importance that CSR has for companies within the tobacco industry, but having in mind Palazzo \& Richter (2005) who stated that possibility of social responsibility in the tobacco industry has been heavily criticized. Therefore, this paper will seek to contribute to the overall understanding of the relationship between CSR and business success of the global tobacco industry by identifying the relationship of CSR activities and industry-level financial performance and by investigating the differences between companies within the tobacco industry in this respect.

\section{CSR CONCEPTUALIZATION}

Since the beginning of the popularization of the CSR concept, there were different opinions about its role in the context of business operations. One of the first economists who publicly spoke about this concept, Milton Friedman (1970), pointed out that the only social obligation of companies is to meet the demand of their shareholders and increase profits within the law and business ethics.

Stakeholder theory, which is based on respecting the needs of all stakeholders in decision-making in business operations, is a significant contributor to understanding the CSR and its implementation in the business philosophy of the company. In this aspect, the contribution of business visionary Peter Drucker (Lee, 2008) is particularly significant. According to Smith $(2011,2)$, "the inclusion of strategic philanthropy, innovation, environmental sustainability and transparency demonstrate how diverse and 
far-reaching CSR has become embedded into management strategy".

Controversies have arisen over the attributes of the concept of "corporate social responsibility" - CSR, since the 1930's, when it started to be mentioned in the literature, and different scholars put forward different views and, more or less accepted definitions. International standard ISO 26000 was developed in 2010 with the purpose of unifying the definition of CSR. It provides guidelines for social responsibility of private and public sector organizations and it sets out seven basic criteria, all contained in the current definitions of CSR (organizational governance, involvement in the community and its development, human rights, labor practices, environment, fair operating practices, consumer issues). However, the standard neglects guidelines on the use of key management practices in terms of achieving the overall goals of CSR and is of limited significance for global corporations.

There is a vast literature on the topic of CSR, which somehow complicates the systematization and classification of the results of earlier researches, especially since classification can be based on principles, strategic tools, dimensions, activities of CSR, and more.

Different authors use different principles in CSR's definition; for example, Carroll (1979) points out three fundamental principles that define the activity of CSR: sustainability, accountability, and transparency. According to Carroll (1991), a socially responsible company must be making a profit, obey the laws of the country in which it operates, act ethically, and be responsible for the social effects of its operations.

The company's strategic tools according to the Wood's CSP model - Corporate Social Performance Model (1991), are divided into three groups: the company's effects on community, the community programs that the company introduces to carry out CSR, politics that the company is developing to address the social issues and stakeholder requirements. Vilanova et al. (2009) emphasize five dimensions of CSR: vision, community relations, workplace, responsibility, market.

\section{LITERATURE REVIEW}

Because of the different needs of stakeholders and the abilities of CSR to create added value for the company, the interest in the analysis of the interdependence of CSR and the company's financial results, as well as the characteristic activities of the company to be taken into account, increased. Some authors (Karnani, 2010) state that CSR activities increase costs without satisfactory benefits, badly affecting the performance and that they are in conflict with the activities that maximize the benefits. Examples of such activities are voluntary donations, developing plans for community improvement, business practices that reduce pollution, and others. On the other hand, Ullmann (1985) analyzed 13 studies on US-based companies regarding the relationship between CSR and financial results and he failed to prove that there is an unambiguous tendency. Nevertheless, most studies show a positive relationship between CSR and financial performances of companies, as can be seen in the following parts of this paper.

Pava and Krausz (1996) systematized the results of 21 studies, 12 of which showed a positive relationship between CSR and the financial results of the company. Waddock and Graves (1997) confirm that CSR and financial results are interdependent. Preston and O'Bannon (1997) and Choi et al. (2010) take CSR activities as dependent variables, 
and parameters of financial success as independent variables, and show a positive relationship. Sims (2003) and Kotler and Lee (2009) argue that CSR (independent variable) leads to profitability (dependent variable) in the long run.

Orlitzky et al. (2003) with meta-analysis conducted at 52 studies confirm that book value of the company (measured by ROA) is more responsive to activities of CSR than market value (measured by Tobin's $Q$ ratio). Incompatibility in results may be due to different methodological approach and the choice of variables, as well as due to the choice of subject, place and time of analysis.

When examining the relationship between CSR and financial performance, other factors affecting this relationship have been observed. Robertson and Nicholson (1996) determine industry as a factor which affects the type of CSR program implemented, given the company's direction towards specific interest groups. Thus, pharmaceutical and chemical industries are focused on employees, and the industry of consumer goods, tobacco and newspaper industries to consumers. Griffin and Mahon (1997) suggest that studies of the relationship between CSR and financial performance should be carried out on companies grouped by industry, as companies in different industries focus on different social problems, and the degree of stakeholders' engagement is different. McWilliams and Siegel (2000) state that the size of the company, the industry environment, the business culture and exposure to risks need to be taken into consideration when examining CSR. Several studies have demonstrated the inadequacy of CSR examination if the industry is not included as a variable in the model. Sweeney and Coughlan (2011), after analyzing 28 FTSE4Good companies $^{1}$, concluded that the industry in which the company operates has a significant impact on the choice of stakeholders that the company "addresses" in its annual report. Cai, Jo \& Pan (2012), using an extensive US sample from 1995 to 2009 , found that CSR engagement of firms in controversial industries (such as tobacco, gambling, alcohol, weapons, oil...) positively affects firm value after controlling for various firm characteristics. Kavaliauskè and Stancikas (2014) have examined the attitude of the population towards companies that declare themselves as socially responsible in the sectors of finance and telecommunications and found that in these sectors consumers prefer the quality of service and customer satisfaction. The scholars Gherghina et al. (2015) conducted a comprehensive survey on a sample of US companies that are listed on the NASDAQ stock market in the period 2008 - 2011. Using the panel data regression models, the study confirmed that social responsibility has a positive effect on the value of the company, and as factors affecting the CSR, they used firm size, financial leverage, growth and listing on the stock market. They also found a significant negative relationship between CSR index and firm size.

Without going into further analysis of the results of earlier studies, all those mentioned so far clearly indicate the direction, focus, and purpose of further research. Furthermore, several specific questions which have arisen and encouraged this research are: If there is a need to group companies by industry when examining the relationship between CSR and business success, what kind of relationship can be found in one controversial industry, such as the global tobacco industry? Do the results vary when business success in the industry is measured using accounting compared with market-based measures? Is there a difference between companies operating within the global tobacco industry in this

\footnotetext{
FTSE4Good companies belong to the stock market index based on a range of CSR criteria. The FTSE4Good Index was launched in 2001 by FTSE Group, a British provider of stock market indices (wholly owned by the London Stock Exchange Group).
} 
respect? Thus, the purpose of this research is to fill the research gap in understanding the relationship between CSR and business success of the global tobacco industry.

\section{METHODOLOGY}

In the next chapter the research methodology is presented, as well as the reasons behind the selection of methods, data samples, and variables. The research approach is based on the results of earlier studies of the relations between CSR and financial performance, while the choice of the tobacco industry as the object of research determined the final design of this research.

\subsection{Research methodology}

The research will use descriptive statistics methods, regression analysis, and correlation analysis. Descriptive statistics will be used to describe data samples of chosen companies, a regression analysis to determine the extent of a connection between two or more variables, and a correlation analysis to determine the nature and degree of correlation between the activity of CSR and financial performance of the company. The obtained empirical results will be tested on the example of companies operating within the global tobacco industry. The abovementioned statistical methods were used by many other scholars when they empirically evaluated the relationship between corporate social responsibility and financial performance and they proved to be relevant in explaining this relationship. On that trail, those methods are used by Setiawan \& Tjiang (2012) when assessing correlation between financial performance and CSR activities of Indonesian consumer goods industry and by Škare \& Golja (2012) when analyzing the importance of socially responsible behavior with regards to financial performance of CSR and non-CSR corporations.
When examining the relationship between the activities of CSR and financial variables of the model, a simple linear regression model within the Excel Data Analysis tool will be used. This model is often used to evaluate the relationship between independent and dependent variables so Simpson and Kohers (2002) use it to assess the impact of CSR on the financial performance of the company, as well. The intensity of the connection will be read from the R-squared value, and the results will be considered reliable with the significance level not less than $5 \%$.

\subsection{An exploratory sample}

The tobacco industry has been chosen as a subject of this research, precisely because of the controversy it is causing in the public. Companies within the tobacco industry supply the market with products of whose health hazards they warn the public, but consumers still consume them, being (more or less) aware of the risks of their consumption.

The research sample is based on objective, reliable and generally accepted standards, such as those provided by the global media company Forbes. Ranking according to Forbes Global 2000 (annual ranking of the top 2,000 public companies in the world) is based on a composite rating obtained from equally weighted measures of sales revenue, profit, assets, and market value. The 2016 list (published in 2017), which was used for this research, according to Forbes (2016) "features public companies from 63 countries that together account for $\$ 35$ trillion in revenue, $\$ 2.4$ trillion in profit, $\$ 162$ trillion of assets, and have a combined market value of \$44 trillion". To secure the assumptions for a comprehensive research framework, the largest companies operating in the global tobacco industry were chosen from the 2016 Forbes Global 2000 list. The nine largest companies, which together make up $99 \%$ of the market capitalization of 
this industry in 2016 are Imperial Tobacco Group, Philip Morris International, British American Tobacco, Japan Tobacco, Altria Group, Reynolds American, ITC, Gudang Garam, KT \& G (Statista, 2016).

As the Forbes Global 2000 list provides insight only to the "size" of the companies, not to the CSR of the companies, due to the need for a relevant CSR rating, the sample of the companies will be formed according to the CSRHub (Corporate Social Responsibility) rating list.

For the calculation of financial indicators, annual reports publicly available on the websites of the companies will be used. Balance sheet, income statement and cash flow statements will be used.

This approach to data enables longitudinal research without dispersing significant resources on data collection. Since the same research sample is used throughout the observed period, panel analysis is the most appropriate.

\subsection{Model variables}

There is no consensus among scholars on the choice of parameters to be taken into consideration when assessing the financial results of companies. Among the different indicators and approaches, some scholars use accounting-based measures such as Return on Assets (ROA), eg Moon et al. (2014); other scholars use market-based measures such as market value per share, eg Martinez Ferrero and Valeriano (2015); while the third approach combines both groups of performance indicators. Thus, for example, McGuire et al. (1988) argue that the CSR is strongly linked with indicators based on book value compared with indicators based on the market value of the company.

In order to obtain representative results, this study will use a third, joint approach, with $\mathrm{ROA}^{2}$ as a measure based on accounting data of companies and the Tobin's Q ratio ${ }^{3}$ as a measure of market value of the company.

As scientifically founded research is not based on subjective assessments and informal information ${ }^{4}$, but on generally accepted standards, in this research, as a source of estimation of CSR for companies in the sample, the CSRHub will be used as a standard. It is a tool that provides access to the ratings and information on socially responsible and sustainable business for 17,487 companies from 535 industries and 134 countries (CSRHub 2016). CSRHub ranks 12 indicators, three for each of the categories: employment, the environment, community, governance actions ${ }^{5}$. According to CSR rating from 2016, tobacco companies in the sample Forbes Global 2000 are ranked as follows (Table 1).

\footnotetext{
2 ROA estimates the success of the company through the economic efficiency and profitability of invested assets.

3 Tobin's Q ratio assesses the performance of the company by comparing the market value of the company and the replacement cost of assets or market and book value of assets and is an indicator of overvaluation/undervaluation of the company.

4 Today, many companies put the focus on their activities and performance in the area of social responsibility. However, this information is not always formally reported, and even if it is reported, it is not codified. For example, with Fortune 1000 provided by the American business magazine Fortune (which contains 1,000 most successful US companies ranked by revenue) $70 \%$ mentioned CSR on their website, but only an estimated $27 \%$ provide a report on CSR. The percentage of smaller companies providing their CSR report is even lower. (CSRHub 2016).

5 CSRHub is the only company that aggregates and normalizes the data sets on the community, employees, the environment and governance gathered from reliable sources and creates a "broad, consistent rating system and database search" (CSRHub 2016). These sources are the leading ESG (Environment, Social and Governance) organizations such as "ASSET4 (Thomson Reuters), CDP (Carbon Disclosure Project), IW Financial, MSCI (ESG Intangible Value Assessment, ESG Impact Monitor, GovernanceMetrics, and Carbon Tracker), RepRisk, Trucost \& Vigeo EIRIS" (CSRHub 2016).
} 
Table 1: CSR rating in the world's largest companies of the tobacco industry in 2016.

\begin{tabular}{|c|c|c|c|c|c|c|c|}
\hline 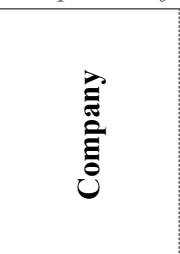 & 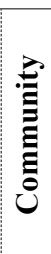 & 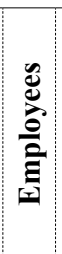 & 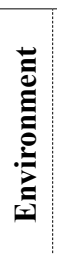 & 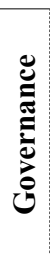 & 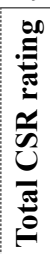 & 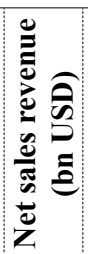 & 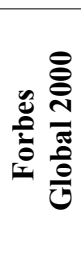 \\
\hline $\begin{array}{l}\text { Imperial } \\
\text { Tobacco } \\
\text { Group Ltd }\end{array}$ & 57 & 72 & 71 & 65 & 66 & 39,1 & 194 \\
\hline ITC Ltd & 61 & 69 & 64 & 67 & 65 & 6,3 & 781 \\
\hline $\begin{array}{l}\text { British } \\
\text { American } \\
\text { Tobacco Plc }\end{array}$ & 55 & 65 & 67 & 60 & 62 & 20 & 177 \\
\hline $\begin{array}{l}\text { Altria Group } \\
\text { Inc }\end{array}$ & 53 & 61 & 63 & 55 & 58 & 18,9 & 226 \\
\hline KT\&G Corp & 57 & 64 & 58 & 45 & 56 & 3,6 & 1216 \\
\hline $\begin{array}{l}\text { Japan } \\
\text { Tobacco Inc. }\end{array}$ & 51 & 63 & 62 & 47 & 56 & 19,2 & 222 \\
\hline $\begin{array}{l}\text { Philip Morris } \\
\text { Internati- } \\
\text { onal Inc }\end{array}$ & 44 & 57 & 66 & 53 & 55 & 26,2 & 184 \\
\hline $\begin{array}{l}\text { Reynolds } \\
\text { American } \\
\text { Inc }\end{array}$ & 46 & 58 & 57 & 50 & 53 & 10,7 & 269 \\
\hline $\begin{array}{l}\text { Gudang } \\
\text { Garam Tbk } \\
\text { Ltd }\end{array}$ & 51 & 52 & 47 & 34 & 46 & 5,3 & 1387 \\
\hline
\end{tabular}

Source: Authors' research according to data by the CSRHub 2016, Statista 2016, Forbes Global 2000, 2016

Table 1 shows top nine largest companies in the global tobacco industry by net sales revenue (and their composite score on the Forbes Global 2000 list), ranked by the highest CSR rating. The CSR rating in four categories (community, employees, the environment, and governance) is taken into account when calculating the average CSR rating of the company.

If the overall CSR rating and net sales revenue are compared, it is clear that the company which achieved the highest net sales revenue, Imperial Tobacco Group Ltd, has the highest overall CSR rating. This certainly is not the rule for other companies in the sample. For example, the company Philip Morris International Inc., ranked second in net sales revenue, is ranked seventh in the overall CSR rating. The company KT\&G Corp, which achieved the lowest net sales revenue, is not rated with the lowest CSR rating but is in the middle (fifth place) of the rating list.

Preferences towards the composite score (derived from equally weighted measures of sales revenue, profit, assets and market value), shown in the Forbes Global 2000 column, are at lower values (if the composite rating is lower, the value of a company is higher). It is interesting to note that the last one on the Forbes Global 2000 list is also the last one on the CSR rating list, and next to last by the net sales revenue (Gudang Garam Tbk Ltd). However, this coincidence is an exception and not a rule, which is clear from the other companies in the sample.

Here already lies an argument in favour of the weak connection between CSR and the performance indicators of the companies in the global tobacco industry.

While CSR is compared with the composite score of the company's performance and the net sales revenue in Table 1, the following research will test (separately) connection between CSR and book value (through ROA) and market value of the company (through the Tobin' $\mathrm{Q}$ ratio). With this approach, we will move away from structuralism to functional connections and relationships that are deeper and more complete. Namely, in the composite score, a large number of heterogeneous factors are involved, but they can be mutually "offset" and make it difficult to conclude if a company has a higher value on the Forbes Global 2000 list because of its book value or market value, or both. On the basis of the results of previous researches, 
which indicate different reactions of accounting compared with market indicators on CSR activities, it is considered that the selected approach to analysis is informative, relevant and scientifically based.

\section{RESULTS}

As earlier stated, the relationship between CSR and the coefficients of ROA and Tobin's Q ratio will be analyzed below. Data related to the entire sample $(99 \%$ of the industry) are presented in descriptive form (cf. table 2), and then tested on the statistical significance of the connection between CSR and performance indicators are conducted (cf. Tables 3 and 4).
Regarding the mean value of financial indicators, while ROA shows a slight growth trend over the years, the Tobin's Q ratio does not show a predictable trend of movement. The median value of ROA is significantly lower (almost twice) than the mean value in each observed year, indicating more low values in the sample. The mentioned phenomenon is even more featured with the Tobin's $\mathrm{Q}$ ratio. The difference between the $\mathrm{min} /$ max value in the observed period is up to 1.4 times higher with the CSR (uniformly), up to 44 times higher with the Tobin's $Q$ ratio (max 2012) and up to 49 times with ROA $(\max 2012)$.

Exploring the reasons behind this difference between the min/max of ROA (with a

Table 2: Descriptive statistics at the (99\%) level of the industry

\begin{tabular}{|l|l|r|r|r|r|r|r|}
\hline Year & Variable & Mean & Median & $\begin{array}{c}\text { Standard } \\
\text { deviation }\end{array}$ & $\begin{array}{c}\text { Minimum } \\
\text { (min) }\end{array}$ & $\begin{array}{c}\text { Maximum } \\
\text { (max) }\end{array}$ & $\begin{array}{c}\text { Sample } \\
\text { size }\end{array}$ \\
\hline \multirow{3}{*}{$\mathbf{2 0 1 1}$} & CSR & 53,47 & 53 & 6,07 & 44 & 62 & 9 \\
& ROA & 0,20 & 0,12 & 0,24 & 0,06 & 0,83 & 9 \\
& Tobin's Q & 4,57 & 1,78 & 7,79 & 0,74 & 25,18 & 9 \\
& CSR & 52,44 & 51 & 5,45 & 44 & 61 & 9 \\
$\mathbf{2 0 1 2}$ & ROA & 0,21 & 0,12 & 0,29 & 0,02 & 0,97 & 9 \\
& Tobin's Q & 5,05 & 1,79 & 9,20 & 0,68 & 29,47 & 9 \\
& CSR & 55,31 & 54 & 5,50 & 47 & 64 & 9 \\
$\mathbf{2 0 1 3}$ & ROA & 0,21 & 0,13 & 0,29 & 0,03 & 0,96 & 9 \\
& Tobin's Q & 4,69 & 1,59 & 8,48 & 0,85 & 27,21 & 9 \\
& CSR & 55,64 & 53 & 5,65 & 48 & 65 & 9 \\
& ROA & 0,21 & 0,11 & 0,30 & 0,05 & 1,00 & 9 \\
& Tobin's Q & 4,35 & 2,02 & 6,73 & 1,15 & 22,16 & 9 \\
& CSR & 56,78 & 54 & 7,11 & 48 & 67 & 9 \\
& ROA & 0,23 & 0,15 & 0,30 & 0,06 & 1,01 & 9 \\
& Tobin's Q & 4,48 & 2,17 & 6,59 & 1,24 & 21,88 & 9 \\
\hline
\end{tabular}

Source: Authors' research according to data by the CSRHub 2016, financial reports of the companies and Stock exchange value (NYSE, LSE, NSE, TSE, KRX, JSX) of the companies at the end of the reporting period

With the exception of the second year (2012), Table 2 shows a slight growth trend in the mean value of CSR. Median supports this trend, with an exception in the fourth year of observation (2014). focus on 2012), the largest is, among other things, the one related to Imperial Tobacco Group Ltd. In that year, the company achieved a significant drop in ROA, which may be explained by a decline in the value of 
Table 3: Regression results at the (99\%) level of the industry

\begin{tabular}{|c|l|r|r|r|r|r|}
\hline \multicolumn{7}{|c|}{ CSR } \\
\hline Indices & Coefficient & $\mathbf{2 0 1 1}$ & $\mathbf{2 0 1 2}$ & $\mathbf{2 0 1 3}$ & $\mathbf{2 0 1 4}$ & $\mathbf{2 0 1 5}$ \\
\hline & P-value & $*$ & $*$ & $*$ & $*$ & $*$ \\
& $\mathbf{r}$ & 0,01 & 0,05 & 0,05 & 0,32 & 0,44 \\
ROA & $\mathbf{V}_{\hat{Y}}$ & $127,86 \%$ & $144,18 \%$ & $142,09 \%$ & $140,09 \%$ & $125,78 \%$ \\
& $\mathbf{R}^{2}$ & 0,00 & 0,00 & 0,00 & 0,10 & 0,19 \\
& $\mathbf{N}$ & 9 & 9 & 9 & 9 & 9 \\
& $\mathbf{P}-$ value & $*$ & $*$ & $*$ & $*$ & $*$ \\
& $\mathbf{r}$ & 0,08 & 0,10 & 0,00 & 0,38 & 0,49 \\
Tobin's & $\mathbf{V}$ & $181,51 \%$ & $193,92 \%$ & $193,27 \%$ & $152,60 \%$ & $137,28 \%$ \\
$\mathbf{Q}$ & $\mathbf{V}_{\hat{Y}}$ & 0,01 & 0,01 & 0,00 & 0,15 & 0,24 \\
& $\mathbf{R}^{2}$ & 9 & 9 & 9 & 9 & 9 \\
& $\mathbf{N}$ & & 9 & & \\
\hline
\end{tabular}

Source: Authors' research according to data by the CSRHub 2016, financial reports of the companies and Stock exchange value (NYSE, LSE, NSE, TSE, KRX, JSX) of the companies at the end of the reporting period

Note: * statistically insignificant

intangible assets by $£ 1.2$ billion in Altadis, Spain (one of their three key subsidiaries) during the economic crisis in that country (Imperial Tobacco Group Ltd: Annual Report 2012). Investigating the Tobin's $Q$ ratio for the companies within the sample, the most significant influence is from company ITC Ltd. The company achieved a strong growth in the market value of total assets in 2012 and outperformed the market trend; S\&P CNX Nifty index ${ }^{6}$ fell by $9 \%$, and the shares of this company increased by more than $24 \%$ (ITC Ltd: Annual Report 2012).

After presenting descriptive statistics, the simple linear regression model of the relationship between the variables, ROA and Tobin's Q ratio as financial indicators, and CSR (cf. Table 3), was performed for companies from the sample of the tobacco industry.

At the level (99\%) of the industry or the sample (cf. Table 3 ), regression results show that the value of the coefficient " $p$ " for the ROA and the Tobin's Q ratio is higher than the significance level of 0.05 for the observed period. It could be concluded that there is no statistically significant relationship between CSR and ROA variables and between CSR and Tobin's $Q$ ratio. Also, the coefficient of variation $\left(\mathrm{V}_{\hat{\mathrm{Y}}}\right)$ shows extremely high values, which brings into question the representativeness of the sample. If only the correlation coefficient (r) was observed, it is clear that only in the last two years there is a weak correlation of both ROA and the Tobin's Q ratio with the CSR. The correlation coefficient for CSR - ROA ratio in 2014 is $32 \%$, while in 2015 it is $44 \%$. The correlation coefficient for CSR - Tobin's Q ratio in 2014 is 38\%, and in 2015 it is $49 \%$.

As can be seen (cf. Table 2), companies in the sample have made more efforts in CSR at the end of the observed period (average

${ }^{6}$ S\&P CNX Nifty is the benchmark stock market index for Indian equity market and it's composed of 50 the largest and most liquid stocks found on the National Stock Exchange of India. 
rating at the level of the industry is growing from 53.47 in 2011 to 55.64 in 2014 and to 56.78 in 2015), which may be a partial explanation of the increase in correlation coefficients in the last two years for both ROA and Tobin's Q ratio. However, for 2014 and 2015 the empirical level of significance ( $p$ ) shows that results cannot be considered reliable (initial results for " $p$ " in Table 3 are marked with symbol * - statistically insignificant).

After regression analysis was performed at the (99\%) level of the industry (questioning the sample representativeness), the simple linear regression model was performed for the companies in the sample throughout the observed period from 2011 to 2015 (cf. Table 4).
The regression results for ROA show that the coefficient " $p$ " is lower than the 0.05 significance level for two companies: Philip Morris International Inc and Reynolds American Inc. For both companies, there is a strong positive correlation between the CSR and the book value of the company represented by the ROA indicator. The correlation coefficient (r) for company Philip Morris International Inc is $93 \%$, while for Reynolds American Inc it is $94 \%$. The regression results for the Tobin's Q ratio show the coefficient "p" lower than the significance level of 0.05 only for company ITC Ltd. This company shows a strong positive correlation ( $\mathrm{r}$ $=90 \%$ ) between CSR and the market value of the company represented by the Tobin's $\mathrm{Q}$ ratio. These results may be linked to the

Table 4: Regression results at the company level in the period $2011-2015$.

\begin{tabular}{|c|c|c|c|c|c|c|c|c|c|c|}
\hline \multicolumn{11}{|c|}{ CSR } \\
\hline \multirow{6}{*}{ 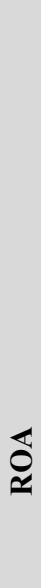 } & & 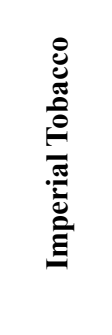 & 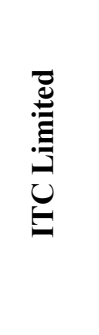 & 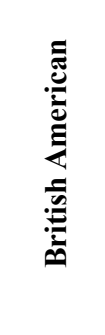 & 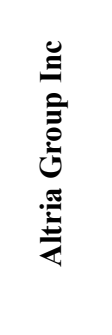 & 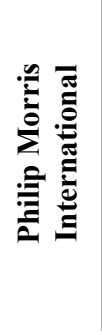 & 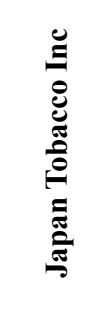 & \begin{tabular}{l}
\multirow{2}{*}{} \\
5
\end{tabular} & 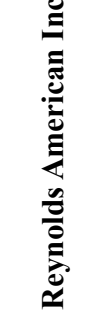 & 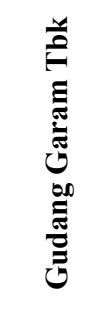 \\
\hline & P-value & $*$ & * & * & $*$ & 0,022 & $*$ & * & 0,020 & * \\
\hline & $\mathbf{r}$ & 0,65 & 0,57 & 0,35 & 0,71 & 0,93 & 0,10 & 0,48 & 0,94 & 0,27 \\
\hline & $\mathbf{V}_{\hat{Y}}$ & $30,64 \%$ & $7,32 \%$ & $13,13 \%$ & $16,28 \%$ & $3,88 \%$ & $15,55 \%$ & $14,73 \%$ & $5,14 \%$ & $22,74 \%$ \\
\hline & $\mathbf{R}^{2}$ & 0,42 & 0,32 & 0,12 & 0,50 & 0,87 & 0,01 & 0,23 & 0,87 & 0,07 \\
\hline & $\mathbf{N}$ & 5 & 5 & 5 & 5 & 5 & 5 & 5 & 5 & 5 \\
\hline 0 & \multicolumn{2}{|c|}{ P-value } & 0,04 & * & * & * & $*$ & $*$ & $*$ & * \\
\hline \multirow{4}{*}{ 薝 } & $\mathbf{r}$ & 0,73 & 0,90 & 0,03 & 0,79 & 0,15 & 0,10 & 0,00 & 0,18 & 0,25 \\
\hline & $\mathbf{V}_{\hat{Y}}$ & $13,72 \%$ & $6,65 \%$ & $7,50 \%$ & $22,83 \%$ & $5,33 \%$ & $18,38 \%$ & $10,37 \%$ & $30,16 \%$ & $32,23 \%$ \\
\hline & $\mathbf{R}^{2}$ & 0,53 & 0,80 & 0,00 & 0,62 & 0,02 & 0,01 & 0,00 & 0,03 & 0,06 \\
\hline & $\mathbf{N}$ & 5 & 5 & 5 & 5 & 5 & 5 & 5 & 5 & 5 \\
\hline
\end{tabular}

Source: Authors' research according to data by the CSRHub 2016, financial reports of the companies and Stock exchange value (NYSE, LSE, NSE, TSE, KRX, JSX) of the companies on the end of the re- 
results of the research by the aforementioned authors McGuire, Sundgren \& Schneeweis (1988), which conclude that CSR is strongly associated with indicators based on book value compared to indicators based on the market value of the company.

Philip Morris International Inc, for which the regression analysis shows a strong positive correlation between CSR and ROA $(r=$ $93 \%$ ) is ranked as seventh of the nine companies in the sample, according to the 2016 ranking. However, it is the only company in the sample that has achieved continuous progress in CSR rating throughout the observed period (CSRHub 2016).

Reynolds American Inc., for which the regression analysis also shows a strong positive correlation between CSR and ROA ( $\mathrm{r}=$ $94 \%$ ) is only at the eighth place of the nine companies in the sample, according to the ranking from 2016. Even though the company has not achieved a continuous improvement in CSR rating, it is worth mentioning that in the years in which it recorded the growth of ROA, it also achieved growth in the CSR rating (2013 and 2014), and vice versa (CSRHub 2016; Reynolds American Inc. 2013, 2014).

ITC Ltd, for which the regression analysis shows a strong positive correlation between CSR and Tobin's Q ratio $(r=90 \%)$ is ranked second from a total of nine companies in the sample, according to the 2016 ranking. It is interesting to add that the company has become one of the most successful companies in the sample according to the CSR rating only in the last two years (2014 and 2015) (CSRHub 2016).

Table 4 shows a medium strong positive correlation between CSR and ROA for the companies Imperial Tobacco Group Ltd, ITC Ltd and Altria Group Inc., and between CSR and Tobin's Q ratio for Altria Group Inc. and
Imperial Tobacco Group Ltd. However, the coefficient " $p$ " in the regression analysis indicates insufficient statistical significance. It is possible that expanding the time frame of observation of these companies would contribute to the increase of statistical significance. However, given their stronger implementation of CSR only in recent years (cf. Table 2), the extension of the time frame could affect the greater dispersion of the values in the sample.

\section{CONCLUSION}

In this paper the analysis of the correlation between the CSR and the financial performance of the companies operating within the global tobacco industry for the period 2011-2015 was performed, on a sample whose value is about $99 \%$ of the total market capitalization of this industry. Results of the research suggest that it is not possible to determine the scientifically based correlation of CSR and selected performance indicators, ROA and Tobin's Q ratio. Obtained results confirm the results of earlier studies in which no statistically significant correlation and unambiguous tendency between these variables have been demonstrated. As the focus of this research is on the tobacco industry, which invests significant resources in CSR, largely because of public pressure, the findings could, among other things, be burdened by the cost inefficiency of investing in CSR activities.

In the second part of the empirical research conducted on the company level, only a few regression analyses (3 out of 18) expressed the value of the coefficient " $p$ " below 0.05 in the observed period of 2011 - 2015. A strong positive correlation between CSR and financial performance for three tobacco companies was confirmed - for two through ROA and for one through the 
Tobin's Q ratio. When applying a regression analysis to a single company, the dispersion of the ROA and Tobin's Q ratio from the mean value decreased, which is in favor of the representativeness of this approach.

Although review of previous research mostly revealed a positive relationship between the CSR and financial performances of the companies, results of this research suggest otherwise. Important scientific contribution of this research is that it confirms the importance of industry in examination of the relationship between CSR and financial performance. Nevertheless, it allows different understanding of the importance of CSR in the industry which core function is in inherent contradiction with CSR. The importance of having short-term financial benefits in such industry falls into the background and other stakeholders' interests, which might be perceived as the fact that increased brand equity resulting from the investments into CSR is gaining in importance. Observed from a different point of view, business success in this industry seems to be influenced by other factors to a larger extent than by CSR.

A number of important limitations need to be considered. Firstly, due to difficulties in finding a universally accepted CSR standard and in ensuring scientifically based research, this paper focused on CSRHub as a standard of CSR. Although it is evident which criteria this standard evaluates, it's not fully transparent how CSRHub rating system is created. Secondly, almost no research has been made on the topic of relationship between CSR and business success in industries which are under the watchful eye of the public, such as the tobacco industry. It is, therefore, difficult to compare results between papers and discover potential disadvantages and space for progress. Thirdly, due to the difficulties in obtaining financial data as well as CSR score at the regional or the country level, the focus was on the global tobacco industry though this approach provides a good overview and a basis for further research.

Options for further research are numerous, from the selecting of other performance indicators as model variables, their defining as independent or dependent, to an extension of the time frame of observation for the companies in the sample. As certain CSR activities need longer period of time to show results, it would be interesting to conduct research with differentiation between shortterm and long-term impact of CSR on business success. Another important endowment would be examination of the relationship between CSR and business success in other controversial industries (like gambling and alcoholic drinks) to compare thus obtained results. Of course, there is a dilemma as to whether such industries as tobacco should be evaluated, in terms of CSR, with the indicators of financial success or should such industries and analyses of the relationship between CSR implementation and the business philosophy of the company be analysed with some other companies' indicators? At any rate, the controversial industries, such as the tobacco industry, are an interesting area for research as the one presented in this paper. 


\section{REFERENCES}

1. Cai, Y., Jo, H. \& Pan, C. (2012), 'Doing well while doing bad? CSR in controversial industry sectors', Journal of Business Ethics, vol. 108, no. 4, pp. 467 -480 .

2. Carroll A. B. (1979), 'A three-dimensional conceptual model of corporate performance', Academy of Management Review, vol. 4, no. 4, pp. 497 - 505.

3. Carroll, A. B. (1991), 'The pyramid of corporate social responsibility: Toward the moral management of organizational stakeholder', Business Horizons, vol. 34 , no. 4 , pp. $39-48$.

4. Choi, J. S., Kwak, Y. M. \& Choe, C. (2010), 'Corporate social responsibility and corporate financial performance: evidence from Korea', Australian Journal of Management, vol. 35, no. 3, pp. $291-311$.

5. CSRHUB 2016, CSRHUB Sustainability management tools, Available at: $<$ https://www.csrhub.com/> (Accessed 10 $0^{\text {th }}$ of April 2017)

6. Forbes 2016, The World's Biggest Public Companies, Available at: $<\mathrm{htt}-$ ps://www.forbes.com/global2000/ list/\#tab:overall $>\quad$ Accessed $15^{\text {th }}$ of March 2017)

7. Friedman, M. (1970), 'The social responsibility of business is to increase its profits', The New York Times, Available at: <http://www.umich.edu/ thecore/ doc/Friedman.pdf $>$ (Accessed $1^{\text {st }}$ of December 2016)

8. Gherghina, Ş. C., Vintilă, G. \& Dobrescu, D. (2015), 'An empirical research on the relationship between corporate social responsibility ratings and US listed companies' value', Journal of Economics Studies and Research, vol. 2015, pp. $1-12$.
9. Griffin, J. \& Mahon, J. (1997), 'The corporate social performance and corporate financial performance debate', Business \& Society, vol. 36, no. 1, pp. 5 - 25.

10. Imperial Tobacco Group Ltd (2012), Annual Report and Accounts, Available at: <http://static.globalreporting.org/rep ortpdfs/2012/5688212f78c6a4f3cb70d5 de9a5ecd19.pdf $>$ (Accessed $10^{\text {th }}$ of June 2017)

11. ITC Ltd (2012), Report and Accounts, Available at: <http://www.itcportal. com/about-itc/shareholder-value/annual-reports/itc-annual-report-2012/pdf/ report-accounts-2012.pdf> (Accessed $10^{\text {th }}$ of June 2017)

12. Jo, H. \& Harjoto, M. A. (2011), 'Corporate governance and firm value: The impact of corporate social responsibility', Journal of Business Ethics, vol. 103 , no. 3, pp. $351-83$.

13. Karnani, A. (2010), 'The case against corporate social responsibility', The Wall Street Journal, Available at: <http:// www92.homepage.villanova.edu/nancy.heck/Articles/Case \%20Against $\% 20$ Social\%20Responsibility\%20WSJ\%20 8-23-10.pdf $>\quad$ Accessed 20 $0^{\text {th }}$ of November 2016)

14. Kavaliauske, M. \& Stancikas, A (2014), 'The importance of corporate social responsibility in Lithuania's finance and telecommunication industries', Procedia - Social and Behavioral Sciences, vol. 110, pp. $796-804$.

15. Kotler, P. \& Lee, N. (2009), Društveno odgovorno poslovanje, Suvremena teorija $i$ najbolja praksa, MEP Consult, Zagreb

16. Lee, M. D. P. (2008), 'A review of the theories of corporate social responsibility: Its evolutionary path and the road ahead', International Journal of Management Reviews, vol. 10, no.1, pp. 53. -73 . 
17. Margolis, J. D. \& Walsh, J. P. (2003), 'Misery loves companies: Rethinking social initiatives by business', Administrative Science Quarterly, vol. 48 , no. 2, pp. 268 - 305.

18. Martinez - Ferrero, J. \& Valeriano, F. A. (2015), 'Relationship between sustainable development and financial performance: International empirical research', Business Strategy and the Environment, vol. 24, no. 1, pp. 20 - 39.

19. McGuire, J. B., Sundgren, A. \& Schneeweis, T. (1988), 'Corporate social responsibility and firm financial performance', The Academy of Management Journal, vol. 31, no. 4, pp. 854 - 72.

20. McWilliams, A. \& Siegel, D. (2000), 'Corporate social responsibility and financial performance: correlation or misspecification?', Strategic Management Journal, vol. 21, no. 5, pp. 603 - 9.

21. Moon, S. G., Bae, S. \& Jeong, M. G. (2014), 'Corporate sustainability and economic performance: an empirical analysis of a voluntary environmental program in the USA', Business Strategy and the Environment, vol. 23, no. 8, pp. $534-46$.

22. Orlitzky, M., Schmidt, F. L. \& Rynes, S. L. (2003), 'Corporate social and financial performance: a meta-analysis', Organization Studies, vol. 24, no. 3, pp. $403-41$.

23. Palazzo, G. \& Richter, U. (2005), 'CSR Business as Usual? The Case of the Tobacco Industry', Journal of Business Ethics, vol. 61, no. 4, pp. $387-401$.

24. Pava, M. L. \& Krausz, J. (1996), 'The association between corporate social-responsibility and financial performance: The paradox of social cost, Journal of Business Ethics, vol. 15, no. 3, pp. $321-57$.

25. Preston, L. E. \& O'Bannon, D. P. (1997), 'The corporate social - financial performance relationship', Business \& Society, vol. 36, no. 4, pp. 419 - 29.

26. Reynolds American Inc (2013, 2014), Financials and filings, Available at: $<$ http://reynoldsamerican.com/Investors /Financials-and-Filings/AnnualReports/default.asp $x>$ (Accessed $10^{\text {th }}$ of June 2017)

27. Robertson, D. C. \& Nicholson, N (1996), 'Expressions of corporate social responsibility in U.K. firms', Journal of Business Ethics, vol. 15, no. 10, pp. 1095 - 106.

28. Setiawan, E. \& Tjiang, G. J. (2012), 'Corporate Social Responsibility, Financial Performance, and Market Performance: Evidence from Indonesian Consumer Goods Industry', Proceedings in ABRC's 2012: the $6^{\text {th }}$ Asian Business Research Conference. Bangkok, Thailand.

29. Sims, R. R. (2003), Ethics and corporate social responsibility - Why giants fall. Praeger, Westport, USA

30. Simpson, W. G. \& Kohers, T. (2002), 'The link between corporate social and financial performance: Evidence from the banking industry', Journal of Business Ethics, vol. 35, no. 2, pp. 97 - 109.

31. Smith, R. E. (2011), 'Defining corporate social responsibility: A system approach for socially responsible capitalism', Master of Philosophy thesis, University of Pennsylvania, Philadelphia, Pennsylvania.

32. Statista (2016), Global tobacco market: leading companies 2016, based on net sales, Available at: <https://www. statista.com/statistics/259204/leading10-tobacco-companies-worldwidebased-on-net-sales/ $>$ (Accessed $20^{\text {th }}$ of March 2017)

33. Sturdivant, F. \& Ginter, J. (1977), 'Corporate social responsiveness, 
management attitudes and economic performance', California Management Review, vol. 19, no. 3, pp. $30-9$.

34. Sweeney, L. \& Coughlan, J. (2011), 'Do different industries report corporate social responsibility differently? An investigation through the lens of stakeholder theory', Journal of Marketing Communications, vol. 14, no. 2, pp. 113 $-24$.

35. Škare, M. \& Golja, T. (2012), «Corporate social responsibility and corporate financial performance - Is there a link?, Ekonomska istraživanja, vol. 25, no. 1, pp. $215-42$.

36. Ullmann, A. A. (1985), 'Data in search of a theory: A critical examination of the relationship among social performance, social disclosure, and economic performance of U.S firms', Academy of
Management Review, vol. 10, no. 3, pp. $540-57$.

37. Vilanova, M., Lozano, J. M., Arenas, D. (2009), 'Exploring the Nature of the Relationship Between CSR and Competitiveness', Journal of Business Ethics, vol. 87, no.1, pp. $57-69$.

38. Waddock, S. A., Graves, S. B. (1997), 'The corporate Social Performance Financial Performance Link', Strategic Management Journal, vol. 18, no. 4, pp. $303-19$.

39. Wood, D. (1991), 'Corporate Social Performance Revisited', The Academy of Management Review, vol. 16, no. 4, pp. $691-717$.

\section{ODNOS IZMEĐU DRUŠTVENE ODGOVORNOSTI I USPJEŠNOSTI POSLOVANJA PODUZEĆA: SLUČAJ GLOBALNE DUHANSKE INDUSTRIJE}

\section{SAŽETAK}

Istraživanje ocjenjuje odnos između društveno odgovornog poslovanja (DOP) i financijskih performansi poduzeća koja posluju unutar duhanske industrije. Prema listi Forbes Global 2000, istraživanjem je obuhvaćeno devet poduzeća koja čine $99 \%$ tržišne kapitalizacije u ovoj grani, što ukazuje na obuhvaćenost analizom gotovo cijele industrije. Analiza ovog istraživačkog problema obuhvatila je razdoblje od pet godina, 2011. - 2015. Za ocjenu DOP-a poduzeća iz uzorka korištena je CSRHub rejting lista koja ocjenjuje četiri kriterija DOP-a, uključenost poduzeća u društvenu zajednicu, brigu o zaposlenima, brigu o okolišu te upravljanje poduzećem. Kako bi se dobili reprezentativni rezultati, za ocjenu financijskih performansi poduzeća koristila su se dva pokazatelja, ROA, kao mjera temeljena na računovodstvenim podacima poduzeća, i Tobin Q indeks, kao mjera tržišnog uspjeha poduzeća. Rezultati istraživanja upućuju na zaključak da na razini industrije nije moguće uočiti statistički značajnu povezanost između DOP-a i financijske uspješnosti poduzeća duhanske industrije, već je istu moguće potvrditi tek selektivno, na razini pojedinih poduzeća i pojedinih pokazatelja.

Ključne riječi: društveno odgovorno poslovanje, duhanska industrija, financijske performanse 
